\title{
Nonstationarity of the electrical resistivity and soil moisture relationship in a heterogeneous soil system: a case study
}

\author{
Didier Michot ${ }^{1, *}$, Zahra Thomas $^{1, *}$, and Issifou Adam ${ }^{1,2}$ \\ ${ }^{1}$ AGROCAMPUS OUEST, UMR1069, Soil Agro and hydroSystem, 35000 Rennes, France \\ ${ }^{2}$ Institut National de la Recherche Agronomique du Niger, Département Gestion des Ressources Naturelles, \\ BP 429, Niamey, Niger \\ *These authors contributed equally to this work.
}

Correspondence to: Didier Michot (didier.michot@agrocampus-ouest.fr)

Received: 24 July 2015 - Published in SOIL Discuss.: 18 September 2015

Revised: 12 May 2016 - Accepted: 28 May 2016 - Published: 20 June 2016

\begin{abstract}
Understanding the role of vegetation in the interface between the atmosphere and groundwater is the most decisive key in analyzing the processes involved in water transfer. The main effect of vegetation is its root water uptake, which significantly modifies the processes involved in water transfer in the vadose zone. This paper focuses on mapping temporal and spatial changes in soil moisture using electrical resistivity tomography (ERT). The main objective is to assess how electrical resistivity (ER) is useful for mapping water distribution along a heterogeneous toposequence crossed by a hedgerow. Ten ERT were performed over the studied period for a $28 \mathrm{~m}$ long toposequence and compared to matric potential and groundwater level measurements. Soil volumetric water content (VWC) was predicted with two methods: (i) from ER using the Waxman and Smits model (ii) and from matric potential using an experimental retention curve fitted by a Van Genuchten model. Probability density functions (PDFs) of our set of data show that the largest change in mean ER and matric potential was observed in the topsoil layer. We then analyzed the consistency between ER and point measurements in this layer by extracting the arrays at the junction of ER grids and point measurements. PDFs of ER maps at each monitoring time (from T01 to T10) were also calculated to select the most contrasting distributions, corresponding to the wettest (T06) and driest states (T10). Results of ER were consistent with matric-potential measurements, with two different behaviors for locations inside and outside the root zone. A consistent correlation between VWC values from the Waxman and Smits model and those obtained from the retention curve was observed outside the root zone. The heterogeneous soil system inside the root zone shows a different pattern in this relationship. A shift in the relationship between ER and soil moisture for the locations outside and inside the root zone highlights the nonstationarity between wet and dry periods inside the root zone. The equivocal behavior of this relationship shows the limitation of using ER to predict soil moisture in a heterogeneous soil system. Such systems were actually related to the high hedgerow root density and also to a particular topographical context (ditch and bank) that is encountered in Brittany and throughout northwestern Europe.
\end{abstract}




\section{Introduction}

Understanding the role of vegetation in the interface between the atmosphere and groundwater is the most decisive key for analyzing the processes involved in water transfer. The main impact of vegetation is root water uptake and hydraulic redistribution, which significantly modifies the processes involved in water transfer in the vadose zone. In western Europe, hedgerow networks are a common and ancient tree alignment surrounding agricultural fields. Hedgerow removal due to farm enlargement is the major land use change since the Second World War. Previous studies suggest a significant impact of hedgerows on soil moisture (Caubel, 2001; Thomas et al., 2008) and rainfall distribution (Ghazavi et al., 2008). Many studies have explored the effect of hedgerows surrounding wetlands on water fluxes and the subsequent increase in transpiration (Thomas et al., 2012) and decrease in nitrate concentration (Grimaldi et al., 2009). The benefits of hedgerows in soil conservation have been highlighted by Walter et al. (2003). In agricultural landscapes throughout the world, combining trees and crops seems an appropriate alternative for providing the benefits of trees to crop requirements. Water availability can be monitored using direct and indirect soil moisture sensors. As significant spatial variability exists in the vadose zone, a dense array of sensors (e.g., tensiometers, time-domain reflectometer (TDR), piezometers) is usually required. However, a high density of sensors is not only expensive, but drilling to install them can disrupt hydraulic contact and induce preferential flow. Noninvasive geophysical imaging techniques, such as electrical resistivity tomography (ERT), might be an alternative way to monitor matric-potential distribution in the soil in relation to root water uptake. Specifically, ERT allows the spatial distribution of soil electrical resistivity (ER) to be mapped in 2-D or 3-D.

As a geophysical signal, ER is related to varying physical and chemical characteristics. ERT helps to identify spatial and temporal soil physical properties (e.g., structure, water content, fluid composition). Many applications of ERT have been developed over the last 20 years, from the assessment of solute transport in aquifers (Müller el al., 2010) to the detection of soil salinity in irrigated zones (Adam et al., 2012). Samouëlian et al. (2005) reviewed ER as a function of soil properties, described the main electrical devices for 2-D or 3-D surveys and explained the basic principles of data interpretation. Soil ER mainly involves the constant physical properties of the soil, such as clay content, but it also involves variable properties over time, such as soil water content, soil water electrical conductivity and temperature (Ward, 1990; Samouëlian et al., 2005). Thus, time-lapse ERT is an alternative way to monitor spatial and temporal water flux providing larger spatial scales. Numerous studies have tested the potential of ERT to monitor water flux processes, such as infiltration in unsaturated conditions (Descloitres et al., 2008; Al Hagrey and Michaelsen, 1999; Michot et al., 2001, 2003;
Yamakawa et al., 2012; Zhou et al., 2001). Thus, in order to use ER to monitor volumetric water content (VWC), it is necessary to perform a laboratory or field calibration (Michot, 2003) or to develop a pedotransfer function integrating data about soil properties (Hadzick et al., 2011; Brillante et al., 2014). Another alternative is to use a petrophysical model linking ER to VWC. Various petrophysical models have been derived from the law of Archie (1942) and were developed first for pure sand (without any clay). The empirical Waxman and Smits (1968) model based on the law of Archie (1942) takes into account the effect of clays on resistivity and has been successfully applied in its simplified form to agricultural soils (Garré et al., 2011; Beff et al., 2013). Among five petrophysical models tested on a loamy soil to predict VWC and soil bulk density, the Waxman and Smits model appeared more consistent for electrical resistivity values $>100 \Omega \mathrm{m}$ (Laloy et al., 2011), which are often observed in dry soils. For lower ER values $(<100 \Omega \mathrm{m})$, the volumeaveraging method (Pride, 1994; Linde et al., 2006) outperformed other tested models. A review of possible techniques to develop models that allow the use of ERT to spatialize soil water availability to plants was presented by Brillante et al. (2015). They describe methods and models to calibrate ER using TDR measurements.

Several authors have also described the distribution and biomass of tree roots using ERT (Amato et al., 2008, 2009; Zenone et al., 2008; Al Hagrey and Petersen, 2011; Rossi et al., 2011). Root presence in the soil is characterized by a highly resistive area close to the tree trunk (Amato et al., 2008; Al Hagrey, 2007), and soil ER varies with root biomass density (Rossi et al., 2011). However, understanding the spatial heterogeneity of soil water content and the hydrological processes in a hedgerow landscape implies estimating the root water uptake of tree hedgerows. Werban et al. (2008) used ERT to monitor temporal changes in the distribution of soil water content in the root zone of a lupine plant in the laboratory. Garré et al. (2011) used ERT to measure soil water depletion caused by barley plants grown on an undisturbed soil monolith in a lysimeter. Michot et al. (2003) monitored soil water fluxes with ER imaging in an agricultural field after irrigation and detected preferential dryness just below cultivated maize plants. Similar observations of root zone drying, highlighted by an increase in ER, were shown in Mediterranean contexts by Al Hagrey (2007) and Nijland et al. (2010) on soils planted with cork oaks or covered by seminatural vegetation of evergreen shrubs and trees. However, only Srayeddin and Doussan (2009) have quantified and mapped root water uptake of maize and sorghum in field conditions using time-lapse ERT. Recently, Garré et al. (2012) tested the ability of different ERT electrode arrays to detect soil moisture dynamics in a monocropping and an intercropping system. The most promising electrode array they tested was a combination of dipole-dipole and Wenner measurements. This effective electrode array was then tested for monitoring soil water dynamics in mixed cropping systems 
in the warm and humid tropical climate of Thailand (Garré et al., 2013). Most previous ERT work on soil water depletion induced by tree or plant root water uptake has focused on well-drained soils.

The present study had a double goal: (i) to investigate effects of hedgerow roots on soil moisture using ERT and point monitoring and (ii) to verify the correlation between ER and soil moisture in a heterogeneous soil system. Soil water depletion was estimated by point measurements of soil matric potential over the studied period. ER values were converted to soil volumetric water content (VWC) using the Waxman and Smits petrophysical model. VWC values were compared to those obtained from matric potential using a retention curve. Our case study focused on a toposequence located in a hillslope whose hydrology was controlled by shallow groundwater. The toposequence was located in a bottomland crossed by a hedgerow. The hydrological year was particularly wet.

\section{Materials and methods}

\subsection{Study site}

The study site was located in Brittany, western France. Hillslope hydrology was controlled by shallow groundwater developed in schist bedrock with silt loam soils. An oak hedgerow (Quercus robur) running north to south, planted perpendicular to the slope, created a clear barrier between two contrasting zones. Upslope of the hedgerow, the only land use was well-drained hillslope soils with permanent pasture. Downslope of the hedgerow was a bottomland with waterlogged soils and both permanent pasture and wet-meadow vegetation (Carex spp.). A $28 \mathrm{~m}$ toposequence perpendicular to the hedgerow was established from $16 \mathrm{~m}$ upslope of the hedgerow (UP16) to $12 \mathrm{~m}$ downslope (DW12). The mean slope was 4.8 and $11.8 \%$, respectively, on the toposequence upslope and downslope of the hedgerow. The difference in elevation between UP16 and DW12 was about 2 m (Fig. 1). At the study site, the wetland extended from $10 \mathrm{~m}$ downslope of the hedgerow to the stream.

Long-term (32-year mean) annual rainfall $(R)$ at a nearby weather station (Le Rheu, $5 \mathrm{~km}$ from the study site) was $\sim 720 \mathrm{~mm}$, annual potential evapotranspiration (PETPenman) was $\sim 650 \mathrm{~mm}$, and annual air temperature was $\sim 1.7^{\circ} \mathrm{C}$, ranging from $5.4^{\circ} \mathrm{C}$ in January to $18.4^{\circ} \mathrm{C}$ in $\mathrm{Au}-$ gust (Ferren, 2004). During the studied period, rainfall and PET data were collected at the Saint-Jacques meteorological station $\left(48^{\circ} 4^{\prime} 12^{\prime \prime} \mathrm{N}, 1^{\circ} 43^{\prime} 36^{\prime \prime} \mathrm{W}\right), 5 \mathrm{~km}$ from the study site. Ten monitoring times from 10 March to 13 August 2007 are denoted T01 to T10. Cumulative rainfall and PET-Penman were calculated between each monitoring time (T01 to T10) (Fig. 2a). Annual net rainfall (rainfall-PET) of 7 years (from 2000 to 2007), highlights that the hydrological year studied was particularly wet (Fig. 2b). During the monitoring period, the net rainfall (rainfall - PET) of each interval between ERTs was higher than that during the same period of the previous 6 years (2001-2006) (Fig. S1 in the Supplement). Also, the lowest net rainfall measured between ERTs during the monitoring period was about $-40 \mathrm{~mm}$, compared to $-150 \mathrm{~mm}$ observed during the previous 6 years. Thus, the hydrological year studied was particularly wet.

\subsection{Soil organization and properties}

The organization and geometry of soil horizons was described in a 2-D vertical cross section of the toposequence in a trench $2 \mathrm{~m}$ deep and $28 \mathrm{~m}$ long that was excavated parallel to the toposequence (Fig. 1). Soils and horizons were identified according to the World Reference Base of Soil Resources (FAO, 2006).

The geometry and properties of these pedological horizons vary greatly over small spatial scales, according to previous observations in a similar hedged landscape (Walter et al., 2003; Follain et al., 2009). We observed a Luvic and Stagnic Cambisol and a Stagnic Fluvisol from upslope to downslope, respectively. In the upslope zone, the thickness of the organo-mineral loamy A horizon increased from 0.4 to $1.1 \mathrm{~m}$ from upslope to the ditch close to the hedgerow (Fig. 1). In the downslope zone, the organo-mineral A horizon was thinner and ranged from $0.1 \mathrm{~m}$ below the hedgerow to $0.5 \mathrm{~m}$ at the boundary with the epistagnic fluvic horizon (B1 horizon, see Fig. 1) of the wetland. The complexity of this soil's spatial organization within the hedged landscape is controlled by past and recent redistribution processes, such as hydric and tillage erosion. Also, past and recent hedgerow network design may influence soil organization, as highlighted by Follain et al. (2009). Increasing thickness of the A horizon from upslope to the hedge is due to the anti-erosive effect of the hedge as a barrier. Soil horizon organization differed slightly below the hedgerow, particularly due to anthropogenic topographical features, such as under the ditch and in the soil bank (Fig. 1). Soil thickness above the weathered schist bedrock varied greatly. It ranged from 1.3 to $1.6 \mathrm{~m}$ near the hedgerow in the upslope zone to less than $0.9 \mathrm{~m}$ in the downslope zone. Redoximorphic features appeared below a depth of $0.5 \mathrm{~m}$ in the upslope zone and began at the soil surface in the downslope zone.

Soil texture, bulk density and hydraulic conductivity were measured at seven locations along the toposequence (Fig. 1) where soil matric potential $(\Psi)$ and groundwater level (GWL) were monitored: 16, 8, 4 and $1 \mathrm{~m}$ upslope (UP16, UP8, UP4 and UP1) and 2, 6 and $12 \mathrm{~m}$ downslope (DW2, DW6 and DW12).

The clay content of shallow and organo-mineral horizons ranged from 14.6-16.0\% in the upslope zone and exceeded $20 \%$ in the downslope zone (Ghazavi et al., 2008). At greater depths, the endostagnic B horizon observed in the Luvic Cambisol (UP16) had a clay content of $23.3 \%$, but the highest clay content was observed in the Stagnic Fluvisol in the bottomland (DW12). It ranged from $24.7 \%$ in the shallow 


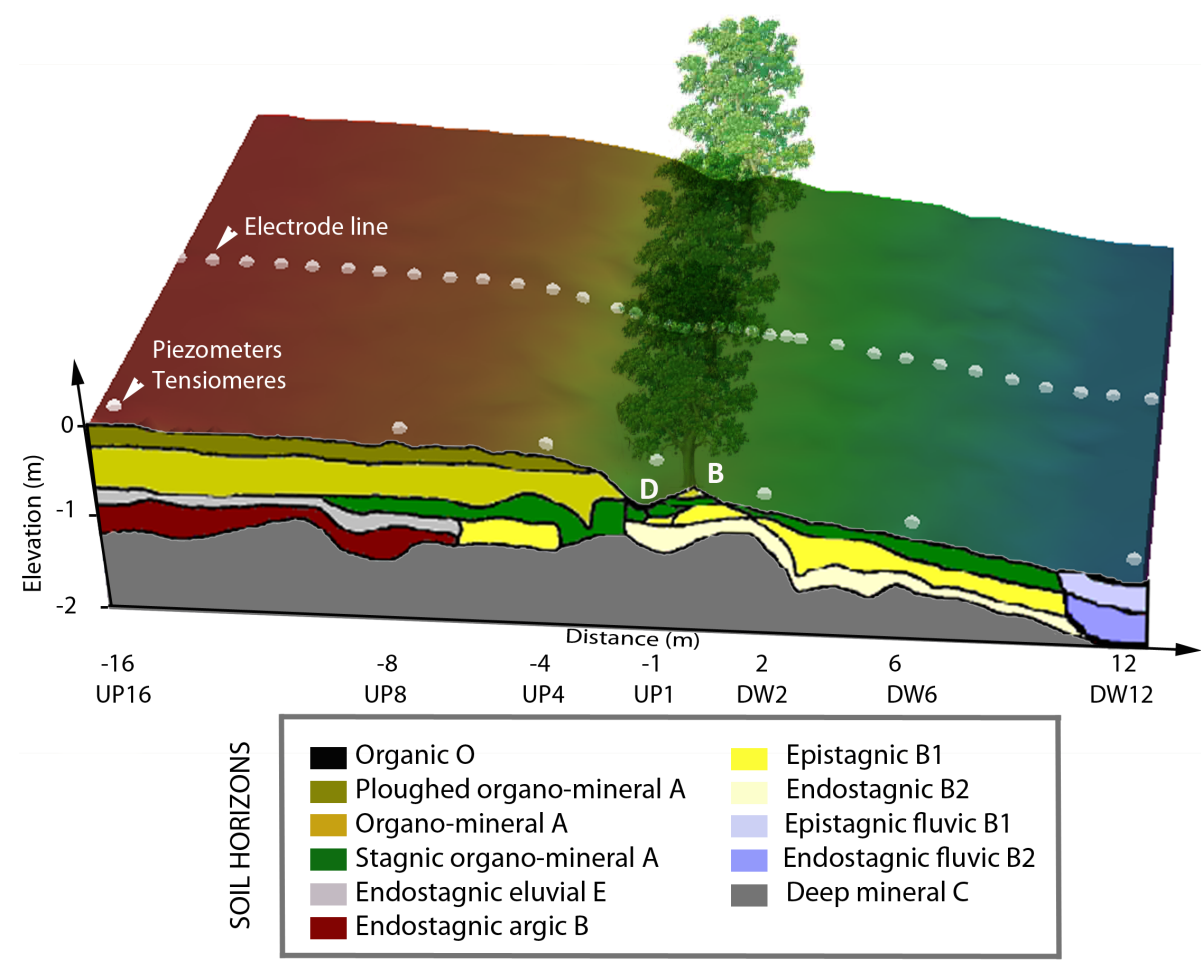

Figure 1. Experimental setup and soil horizon organization along the toposequence. Soil was excavated up from 16 m upslope (UP16) to $12 \mathrm{~m}$ downslope (DW12). Soil horizons are named according to the World Reference Base for Soil Resources (FAO, 2006). D and B indicate ditch and bank locations, respectively. Each monitored location (UP16, UP8, UP4, UP1, DW2, DW6 and DW12) was equipped with five tensiometers and one piezometer.

epistagnic fluvic B1 horizon to $27.1 \%$ in the endostagnic fluvic $\mathrm{B} 2$ horizon at depths of 0.4 to $0.9 \mathrm{~m}$. At depth, the schist saprolite (C mineral horizon) had a loam-sandy-clayey texture (Table I in Ghazavi et al., 2008). We observed several coarse-particle accumulations (e.g., stones, quartz veins) in the 2-D vertical soil cross section, in particular in the upslope zone and near the ditch along the hedgerow.

As expected, soil bulk density increased with soil depth at all distances along the toposequence (Fig. S2a and b). Vertically, variability in bulk density in the upslope zone was lower than that in the downslope zone. Horizontally, in the upslope zone, soil bulk density increased with distance from the hedgerow from 1.3 (UP4) to 1.6 (UP16) at $5 \mathrm{~cm}$ deep and from 1.5 (UP4) to 1.7 (UP16) at $100 \mathrm{~cm}$ deep (Fig. S1a and b). Additionally, bulk density was higher in the topsoil layer $(0-50 \mathrm{~cm}$ deep) in the upslope than in the downslope zone.

Soil hydraulic conductivity was measured at conditions of near saturation, i.e., at a low water potential of $-0.05 \mathrm{kPa}$, with a Decagon $4.5 \mathrm{~cm}$ diameter mini disk infiltrometer (Decagon Devices, 2006). Soil hydraulic conductivity was determined from steady-state flux data according to the Wooding (1968) approach. Multiple depths were measured at each monitored location along the toposequence (Fig. S2c and d). As a function of changes in bulk density, hydraulic conductivity at $-0.5 \mathrm{hPa}$ water potential $\left(K_{(-0.5 \mathrm{hPa})}\right)$ decreased with increasing soil depth at all locations along the toposequence except for DW2, where a singular point was observed at a depth of $60 \mathrm{~cm}$. Mean $K_{(-0.5 \mathrm{hPa})}$ values were significantly higher in the downslope zone $\left(6 \times 10^{-4}\right.$, $5.7 \times 10^{-4}$ and $5.5 \times 10^{-4} \mathrm{~m} \mathrm{~s}^{-1}$ at DW2, DW6 and DW12, respectively) than the upslope zone, especially in the topsoil, i.e., depth $>50 \mathrm{~cm}\left(200 \times 10^{-6} \mathrm{~m} \mathrm{~s}^{-1}\right.$ at UP4, UP8 and UP16). $K_{(-0.5 \mathrm{hPa})}$ values (Fig. S2c and d) were relatively homogeneous in the vertical plane upslope from the hedgerow, while a difference of 2 orders of magnitude was observed between the topsoil and subsoil in the downslope zone. A lower $\mathrm{K}$ and higher bulk density are well-known characteristics of bottomland soils.

The soil surface occupied by roots along the trench was estimated using a quadrat of $1 \mathrm{~m}^{2}$ subdivided into 100 squares of $100 \mathrm{~cm}^{2}$ each (Bréda et al., 1995). First, the quadrat was located at a depth of $10-110 \mathrm{~cm}$ to avoid counting pasture roots in the top layer. Otherwise, roots without woody structure were not considered. For each $100 \mathrm{~cm}^{2}$ square, only the woody roots were counted and summed for the $1 \mathrm{~m}^{2}$ section of the trench, both upslope and downslope, and the percentage of total woody roots that occurred in each section was calculated as presented by Ghazavi et al. (2008). Along the toposequence, vertical root distribution within each $1 \mathrm{~m}$ was 


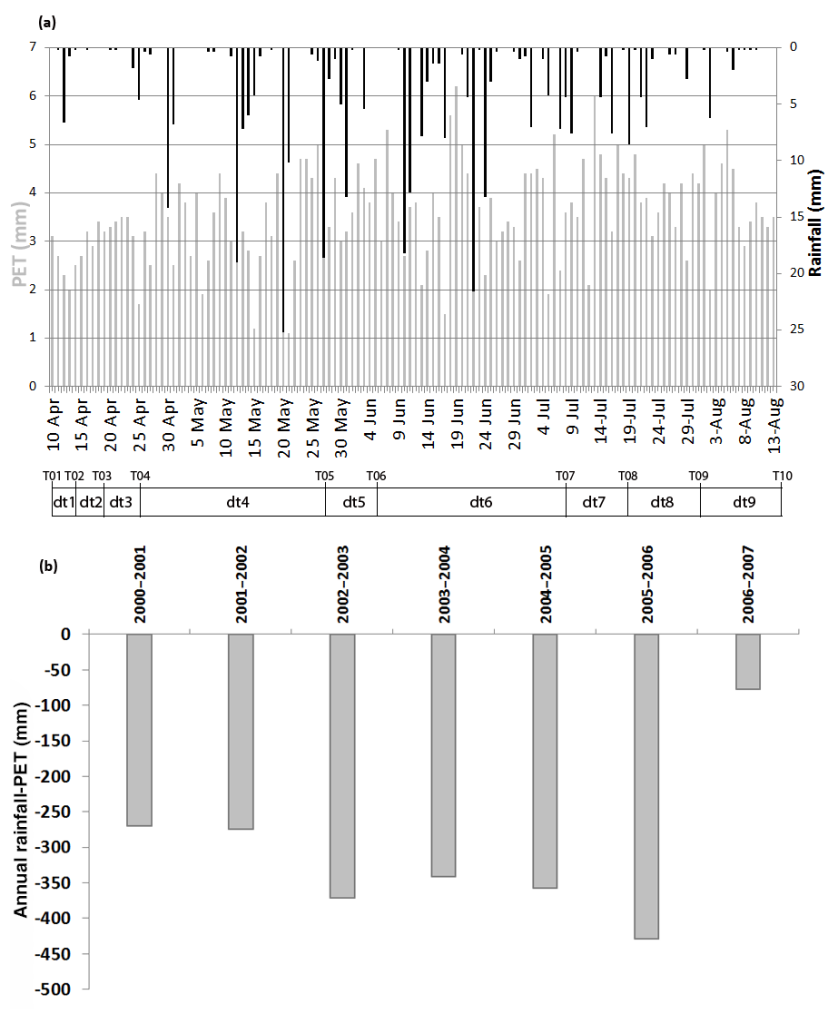

Figure 2. (a) Daily rainfall and potential evapotranspiration (PET) measured during the monitoring period (10 April to $13 \mathrm{Au}-$ gust 2007). ERT measurement dates (T01 to T10) and intervals between them (dt1 to dt10) are indicated along the $x$ axis. (b) Annual net rainfall (rainfall - PET) calculated for the previous 6 years. Annual net rainfall calculated for each interval of the monitoring period and compared to that of the previous 6 years is presented in Fig. S1.

also calculated at four depth classes: 10-50, 50-100, 100150 and $150-200 \mathrm{~cm}$ (Fig. S2e and f). According to the observations of Ghazavi et al. (2008), horizontal distribution of tree roots in the upslope and downslope zones was asymmetric, with $76 \%$ of tree roots located upslope and only $24 \%$ of roots located downslope. Vertically, tree roots reached deeper in the upslope zone than in the downslope zone. Moreover, in the upslope zone, 61,36 and $3 \%$ of roots were, respectively, located $10-50,50-100$ and $100-200 \mathrm{~cm}$ deep. In the downslope zone, $92 \%$ of roots were located $10-50 \mathrm{~cm}$ deep, and only $8 \%$ were $50-100 \mathrm{~cm}$ deep.

\subsection{Hydrological monitoring: point measurements}

Soil matric potential and groundwater level were monitored as described by Ghazavi et al. $(2008,2011)$. Seven locations were monitored continuously with one piezometer and five tensiometers each (Fig. 1). Three piezometers were located at 16,8 and $4 \mathrm{~m}$ upslope of the hedgerow, each with a tube diameter of $11.2 \mathrm{~cm}$ and a total length of $7.5 \mathrm{~m}$, of which $4 \mathrm{~m}$ at its base were screened. The other four piezometers were located at $1 \mathrm{~m}$ upslope and 2, 6 and $12 \mathrm{~m}$ downslope of the hedgerow, each with a diameter of $6.8 \mathrm{~cm}$ and a total length of $4.5 \mathrm{~m}$, of which $2 \mathrm{~m}$ at its base were screened. For each monitored location, five tensiometers were installed at depths of 25, 50, 100, 150 and $200 \mathrm{~cm}$. The vertical soil matric-potential profiles were used to interpret the ER.

\subsection{Electrical resistivity monitoring}

\subsubsection{Time-frame ERT}

Temporal monitoring of ER along the toposequence (Fig. 1) was performed at 10 monitoring times (T01 to T10). Resistivity was measured with a Syscal R1 resistivity meter (Iris Instruments, Orléans, France). The precision of its intensity and voltage was $\pm 0.3 \%$, which is consistent with measurements taken under constant surface conditions. The experimental design included a row of 64 electrodes that were lined up on the soil surface perpendicular to the hedgerow (Fig. 1). With an electrode spacing of $0.5 \mathrm{~m}$, the experimental device measured $31.5 \mathrm{~m}$ long. The electrodes remained on the soil surface during the entire experiment to avoid changes in electrode polarization and ensure high-quality measurements. The resistivity meter followed a preprogrammed measurement sequence, and a multiplexer switched among the electrodes.

A dipole-dipole arrangement was chosen because it allowed the greatest number of measurements for the number of electrodes present, which was advantageous for data inversion. Moreover, the dipole-dipole array was highly sensitive to horizontal changes in resistivity but relatively insensitive to vertical changes. For each resistivity measurement, an electrical current was passed between two adjacent electrodes (dipole $A B$ ), and the potential difference was measured between two other neighboring electrodes (dipole $M N$ ). The bulk ER $\rho_{\mathrm{a}}$ of a half-space measured with a dipole-dipole electrode array is

$\rho_{\mathrm{a}}=2 \pi \frac{\Delta V}{I} \frac{1}{(1 / M A-1 / M B+1 / N B-1 / N A)}=k \frac{\Delta V}{I}$,

where $I$ is the intensity of the current passed between electrodes $A$ and $B, \Delta V$ is the potential difference measured between electrodes $M$ and $N$, and $k$ is the "geometric factor", whose value depends on the type of array. For a dipoledipole array, $k$ is calculated as

$k=\pi(n \cdot(n+1) \cdot(n+2) \cdot a)$,

where $a$ is the spacing (distance, in $\mathrm{m}$ ) between electrodes of each dipole and $n$ is a dipole-separation factor whose value is usually an integer multiple of the distance between the current or potential electrode pair. To obtain the necessary resolution, 646 measurements were taken during each ERT. Measurements were located at 12 pseudodepths of investigation, the first 5 with $a$ of $0.5 \mathrm{~m}$ and $n$ of 1, 2, 3, 4 and 6 . Since the potential measured between $M$ and $N$ decreases rapidly 
with increasing $n$, it is not advisable for $n$ to exceed 6 . To maintain measurement quality at greater depths, which have high signal-to-noise ratios. Three pseudodepths were investigated with $a$ of $1 \mathrm{~m}$ and $n$ of 2, 3 and 4 . The remaining four pseudodepths had $a$ of $1.5 \mathrm{~m}$ and $n$ of 2, 3, 4 and 5 . In a dipole-dipole electrode setup, the spacing between the dipole that passes the current and the dipole that measures the potential difference is gradually increased. By convention, bulk ER measurements are represented at the center of the quadripole and at a depth proportional to the spacing between dipoles. Each ERT required $1 \mathrm{~h}$ and $40 \mathrm{~min}$.

\subsubsection{ERT data processing}

Inverting resistivity measurements is an essential step before interpreting them because the raw resistivity measurements rarely reveal the true structure of the soil. Thus, resistivity sections were inverted with the software RES2DINV (Loke and Barker, 1996) using a smoothness-constrained least-squares method to produce a 2-D subsurface model. In the first iteration, a homogeneous earth model was used as a starting point from which partial derivative values of resistivity could be calculated analytically. For subsequent iterations, a quasi-Newton method was used to estimate the partial derivatives, which reduced computing time. In this method, Jacobian matrices for the homogeneous earth model were used for the first iteration, and those of subsequent iterations were estimated with an updating technique. The model consisted of a rectangular grid. Software determined the resistivity of each mesh, which calculated the ER of each section according to field measurements. An iterative optimization method consisted of minimizing the difference between measured resistivity values and those calculated with the inversion model by minimizing the root mean square error (RMSE). Topographic correction was applied to this inversion process. The cells of the grid obtained (Fig. S3) were defined by their four-corners coordinates. Each ERT was inverted independently, considering the same number of measurements. Further details about inversion methods are available in the literature (Loke and Barker, 1996).

Bulk ER of unsaturated soils decreases when water content increases, and vice versa (Ward, 1990). In saturated zones, changes in bulk ER are usually linked to changes in groundwater electrical conductivity.

During the monitoring period, soil drying due to evapotranspiration was analyzed using statistics of each ER map. A probability density function (PDF) of the map at each monitoring time (T01 to T10) was calculated, and PDFs were compared to select the most contrasting distributions. The lowest ER mean represents the wettest state (T06), while the highest ER mean represents the driest state (T10). The change in ER was calculated between those states and was compared to that in matric potential for the same states.
Table 1. Parameters used to predict volumetric water content in the Waxman and Smits model. Sensitivity analysis of WS using 27 simulations (for $N$ parameters and $m$ values, simulation number is $N^{m}$ ).

\begin{tabular}{cccc}
\hline & $a\left(\mathrm{~S} \mathrm{~m}^{-1}\right)$ & $b\left(\mathrm{~S} \mathrm{~m}^{-1}\right)$ & $n$ \\
\hline Value 1 & 0.059 & $1.00 \times 10^{-3}$ & 1.0356 \\
Value 2 & 0.080 & $1.00 \times 10^{-3}$ & 1.1271 \\
Value 3 & 0.150 & $1.00 \times 10^{-3}$ & 1.3996 \\
\hline
\end{tabular}

\subsubsection{ER conversion to VWC}

To quantify the relationship between ER and matric potential, ER values were extracted at the location of each tensiometer (Fig. S3). ER and matric potential of the topsoil layer (at depths of 25 and $50 \mathrm{~cm}$ ) corresponding to the unsaturated zone were analyzed. ER values were also converted to soil VWC from the Waxman and Smits (WS) model (Waxman and Smits, 1968) simplified by Garré et al. $(2011,2013)$ using Eq. (3).

$\mathrm{SWC}=\left\{\frac{\left[\frac{1}{\mathrm{ER}}-b\right]}{a}\right\}^{1 / n}$,

where $a\left(\mathrm{~S} \mathrm{~m}^{-1}\right), b\left(\mathrm{~S} \mathrm{~m}^{-1}\right)$ and $\mathrm{n}$ are fitting parameters. As explained by Garré et al. (2011), these parameters can be explained in a physical way in combination with porosity: $a$ is related to pore water conductivity, and $b$ is related to soil surface conductivity. The parameter $n$ is related to pore connectivity in the full WS model.

Since the variation range of WS parameters is unknown for the toposequence studied, a sensitivity analysis was performed using the range of the parameters presented by Garré et al. (2011). Their study examined four horizons of an Orthic Luvisol developed in a loess parent material from Germany. Orthic Luvisol has relatively similar pedogenesis and texture to those observed in our toposequence, especially in the upslope zone. For each parameter of the WS model, three values (Table 1) were tested, leading to 27 simulations. VWC values were calculated for each extracted cell grid.

Using the retention curves from Ghazavi et al. (2011), measured in the soil horizons of this studied toposequence, we also converted soil matric-potential data into VWC. Experimental retention curves (Fig. S4) were fitted using the Van Genuchten model (Van Genuchten, 1980) from Eq. (4):

$\theta(h)=\left\{\begin{array}{ll}\theta_{\mathrm{r}}+\frac{\left[\theta_{\mathrm{s}}-\theta_{\mathrm{r}}\right]}{\left\lfloor 1+|\alpha \cdot h|^{n}\right\rfloor^{m}} & \text { for } h<0 \\ \theta_{\mathrm{s}} & \text { for } h \geq 0\end{array}\right.$,

where $\theta_{\mathrm{S}}$ and $\theta_{\mathrm{r}}$ are saturated and residual volumetric water content (VWC $\left.\left(\mathrm{cm}^{3} \mathrm{~cm}^{-3}\right)\right)$, respectively, $h$ is pressure head or matric potential (hPa), and $\alpha, n$ and $l$ are Van Genuchten parameters $m=1-l / n$ (Table S1 in the Supplement). 
Table 2. Statistics of electrical resistivity measurements calculated from the 548 cells of the entire 2-D section (entire domain) at each monitoring time (T01 to T10) of electrical resistivity tomography.

\begin{tabular}{lrrrrrrrrrr}
\hline $\begin{array}{l}\text { Electrical } \\
\text { resistivity } \\
(\Omega \mathrm{m})\end{array}$ & T01 & T02 & T03 & T04 & T05 & T06 & T07 & T08 & T09 & T10 \\
\hline Minimum & 9.2 & 10.5 & 10.9 & 11.8 & 10.6 & 10.7 & 11.4 & 11.7 & 12.1 & 9.3 \\
Maximum & 615.2 & 436.3 & 386.8 & 493.0 & 413.5 & 382.9 & 344 & 354.8 & 384.1 & 722.9 \\
SD & 63.7 & 61.6 & 59.9 & 63.3 & 53.0 & 52.6 & 57.2 & 57.0 & 60.6 & 99.2 \\
\hline Mean & 89.2 & 88.6 & 86.7 & 88 & 78.5 & 78 & 80.8 & 80 & 83 & 104.3 \\
Median & 74.4 & 71.9 & 68.6 & 68.8 & 66.4 & 65.4 & 64.4 & 64.7 & 66.4 & 73.5 \\
\hline
\end{tabular}

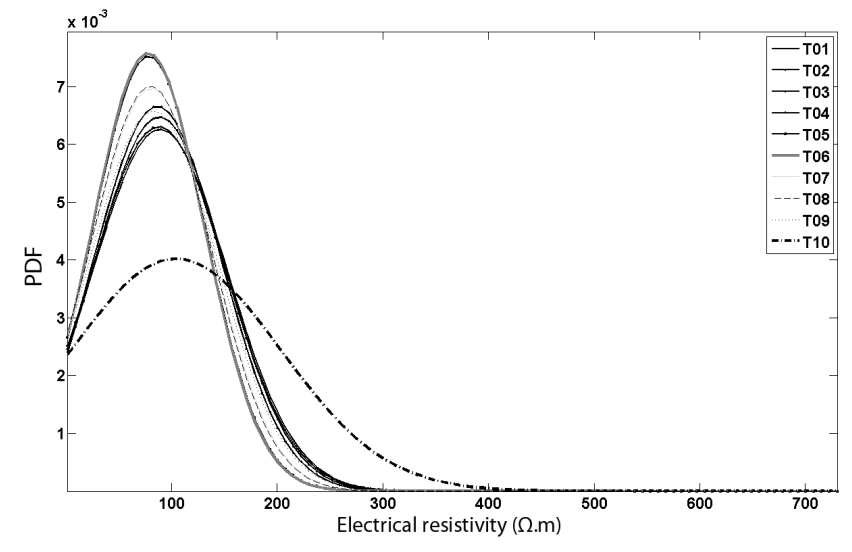

Figure 3. Probability density functions (PDF) estimated from electrical resistivity measurements of the entire 2-D section at each date of electrical resistivity tomography. Curves were fitted with a Gaussian model.

\section{Results}

\subsection{ER sections and statistical distribution of ER}

PDFs of ER at each measurement time (from T01 to T10) were Gaussian and similar to each other except at T10 (Fig. 3). T06 and T10 had the greatest differences in ER value statistics (see Table 2) and were selected as the wet and dry states, respectively. To avoid redundancy, we describe only ER maps of T06 and T10. The 10 measurement dates (from T01 to T10) are given in Fig. S5. At both dates (T06 and T10), a superficial layer was observed from 0 to $0.8 \mathrm{~m}$ depth in the upslope zone with $100-200 \Omega \mathrm{m}$ of ER. In the downslope zone, a small localized resistive structure appeared at a distance of 1-2 $\mathrm{m}$ from the hedgerow. In the upslope zone a resistive layer was formed by the unsaturated well-drained organo-mineral A horizons (Fig. 4). Below this resistive layer, a conductive one was observed with $20-60 \Omega \mathrm{m}$ of ER. The thickness of this conductive structure decreased and reached the ground surface 4-12 m downslope from the hedgerow and had a vertical conductive structure below the hedgerow. A third layer with re- sistivity ranging from 60 to $>200 \Omega \mathrm{m}$ was observed deep $(<-2 \mathrm{~m})$ in the upslope zone and was shallow downslope from the hedgerow and slightly variable along the slope (Fig. 4). Over the studied period, a discontinuity in this layer between upslope and downslope zones appeared vertically below the hedgerow where the lowest resistivity $(<20 \Omega \mathrm{m})$ was observed (Fig. 4). Local resistive structures $(>150 \Omega \mathrm{m})$ were observed at cross-section boundaries, below the ditch and at DW12. These local anomalies were probably due to inversion-method artefacts.

\subsection{Time-frame ERT and matric-potential profiles}

The map of percentage change in electrical resistivity highlights temporal changes in ER between wet (T06) and dry (T10) states (Fig. 5). This map was compared to matricpotential profiles measured for each location at T06 and T10 (Fig. 5). The map of Fig. 5 and point measurements highlight two main areas with large differences in ER. From $16 \mathrm{~m}$ upslope to $7 \mathrm{~m}$ downslope along the toposequence, there is an increase in ER of $20-100 \%$ in the topsoil ( $0-0.9 \mathrm{~m}$ deep) (Fig. 5). In contrast, ER of the subsoil $(>1 \mathrm{~m})$ increased by approximately $20 \%$, with multiple localized structures in which ER decreased by $20-80 \%$. Below the hedgerow, ER increased in a three-pronged pattern, with the upslope branch turning down toward the ditch at $45^{\circ}$, a vertical branch extending beneath the tree, and the downslope branch following the soil surface. Changes in ER were negative from 7 to $13 \mathrm{~m}$ downslope, but the highest decrease in ER $(-80 \%)$ was observed 1-4 m upslope below a depth of $2 \mathrm{~m}$. Changes in soil matric potential corresponded to changes in ER (Fig. 5). According to matric-potential data, the topsoil layer was drier (at depths of 0.25 and $0.5 \mathrm{~m}$ ) than the subsoil (at depths of 1, 1.5 and $2 \mathrm{~m}$ ). Soil matric potential decreased upslope at a depth of $0.5 \mathrm{~m}$ : from -20 to $-152 \mathrm{hPa}$ at $16 \mathrm{~m},-127$ to $-615 \mathrm{hPa}$ at $8 \mathrm{~m}$ and -75 to $-425 \mathrm{hPa}$ at $4 \mathrm{~m}$. Under the ditch $1 \mathrm{~m}$ upslope and $2 \mathrm{~m}$ downslope, the change in soil matric potential confirmed soil drying down to $1 \mathrm{~m}$ and $0.5 \mathrm{~m}$, respectively. The soil was unsaturated to a depth of $0.40 \mathrm{~m}$ at $6 \mathrm{~m}$ downslope. Moreover, even though the soil was saturated by groundwater, electrical resistivity of several local- 

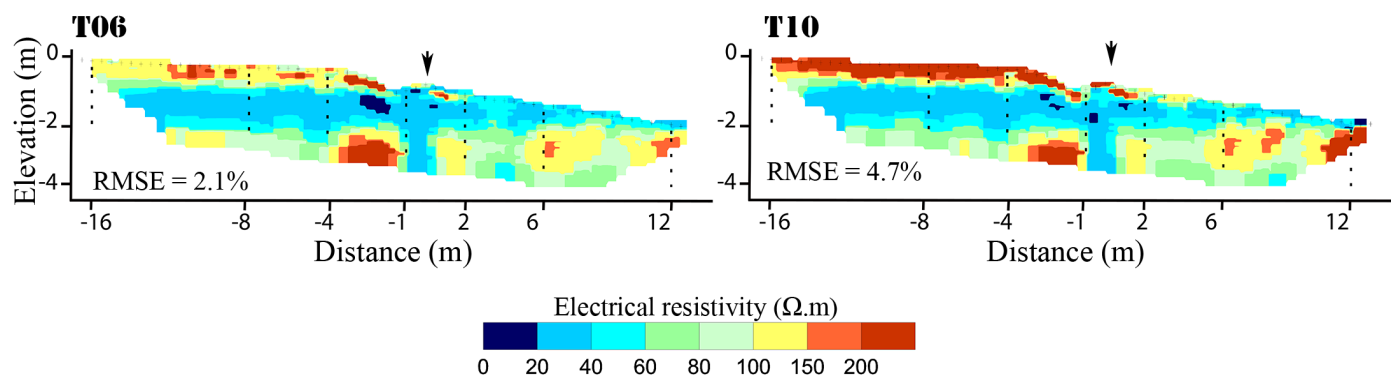

Figure 4. ERT maps for the wettest (T06) and driest (T10) states. The 10 measurement dates (from T01 to T10) are in Fig. S5. Black points indicate tensiometer locations and black arrow the hedgerow location.

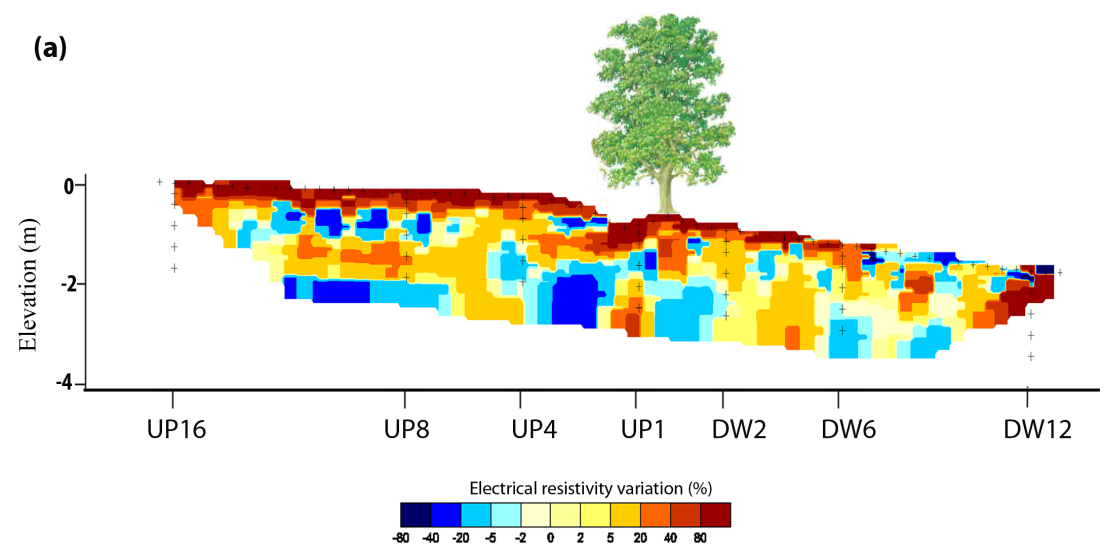

(b)

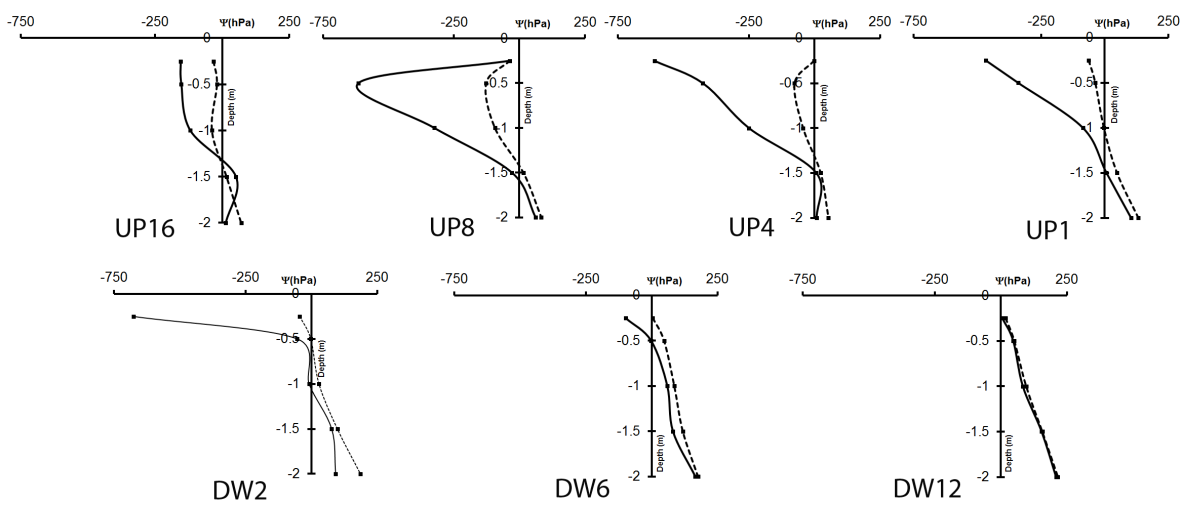

Figure 5. Relationship between ER and soil dryness at the hedgerow proximity. (a) Variation (\%) in electrical resistivity from the wettest state (T06) to the driest state (T10). (b) Measured soil matric-potential profiles at seven locations: UP16, UP8, UP4 and UP1 for upslope and DW2, DW6 and DW12 for downslope. Dashed lines indicate the wettest state (T06) and solid lines the driest state (T10).

ized structures increased by 5-80\% (Fig. 5). These structures were located mainly from 9 to 11 and 1 to $3 \mathrm{~m}$ upslope and 1.5 to 4 and 11 to $13 \mathrm{~m}$ downslope.

PDFs of ER (Fig. 6a) highlight the shift in mean ER between the entire domain and the topsoil layer, as do mean values of matric-potential PDF (Fig. 6b). For the topsoil layer, mean ER was highest when mean matric potential was lowest, corresponding to the driest soil, for both the wet and dry states. The difference in ER between the entire domain and the topsoil layer was about $26 \Omega \mathrm{m}$ for T06 (wet state) and reached $110 \Omega \mathrm{m}$ for T10 (Fig. 6a). For matric potential, the difference between the entire domain and the topsoil layer was about $-73 \mathrm{hPa}$ for T06 and $-200 \mathrm{hPa}$ for T10 (Fig. 6b). The greatest changes in both ER and matric potential were located in the topsoil. In the topsoil layer, change in mean ER and matric potential between the wet and the dry state was about $120.5 \Omega \mathrm{m}$ and $-277 \mathrm{hPa}$ (Fig. 6a and b), respectively. PDFs of ER and PDFs of matric potential show the 


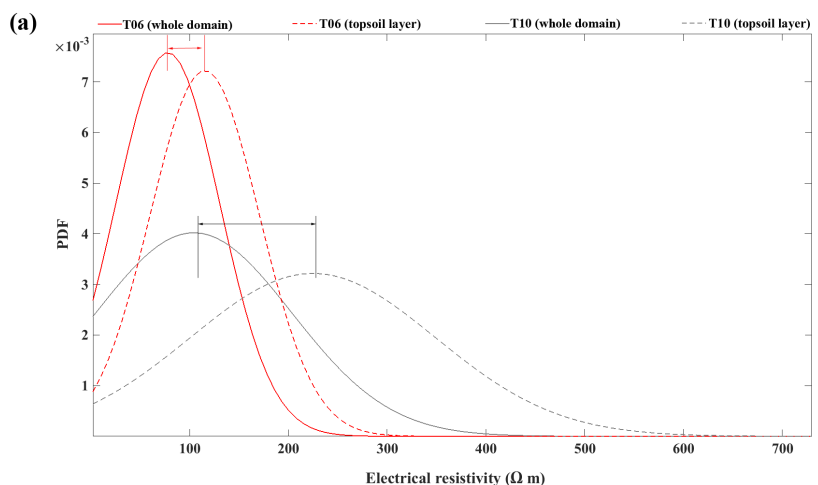

(b)

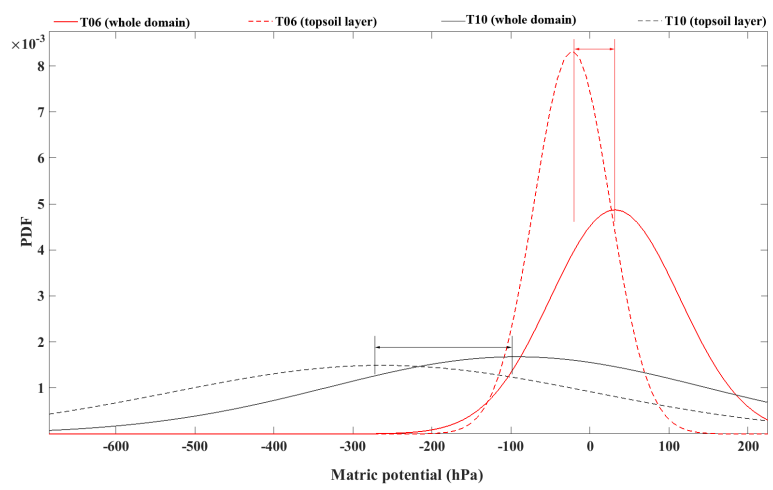

Figure 6. Probability density functions (PDF) of (a) electrical resistivity and (b) matric potential between wet (T06) and dry (T10) states for the entire domain (solid line) and the topsoil layer (dashed line).

same shape between the wet (T06) and dry (T10) state, with an increase in data dispersion due to the highest amplitude during the dry state (Fig. 6).

\subsection{Comparison of point measurements: matric potential vs. ER}

In the unsaturated topsoil, point measurements of matric potential were consistent with ER extracted from each grid (Fig. 7). Two behaviors were observed for the locations inside and outside the root zone (Fig. 7). According to the root system pattern (Fig. S2e and f), we assumed that UP16, UP8 and DW12 were not influenced by the root system and were thus outside the root zone. The locations assumed to be inside the root zone were UP4, UP1, DW2 and DW6. For the locations inside and outside (Fig. 7) the root zone, two different patterns in the relationship between ER and matric potential were observed. Outside the root zone, a linear relationship was observed $\left(R^{2}=0.8\right)$, whereas a dispersion in this relationship appears for the measurements inside the root zone $\left(R^{2}=0.3\right)$. Also, matric-potential range measured outside the root zone remained in the same order of magnitude for both wet and dry states. The wet (T01 to T06 in Fig. 7) and dry (T07 to T10 in Fig. 7) states were analyzed separately.
Upslope, the location situated $4 \mathrm{~m}$ from the hedgerow (UP4) showed a pattern similar to those outside the root zone during the wet state (Fig. 7). UP4 switched to the pattern of the locations inside the root zone during the dry state (Fig. 7).

\subsection{VWC estimation}

Figure 8 shows the relationship between ER and VWC obtained from the WS model with a standard deviation corresponding to the set of WS parameters. The range of variation in VWC prediction from the WS model was highest for small ER values $(<75 \Omega \mathrm{m})$. Outside the root zone (Fig. 8), VWC values predicted from the retention curve were consistent with VWC from the WS model both for wet (Fig. 8a) and dry states (Fig. 8b). Inside the root zone (Fig. 8), VWC values predicted from the retention curve were smaller than VWC from the WS model except for UP4 during the wet state (Fig. 8a). At UP4, VWC predicted from the retention curve was slightly smaller than that predicted by the WS model during the dry state (Fig. 8b).

Figure 9 shows the relationship between VWC estimated from the retention curve and VWC predicted by the WS model. Red and gray circles show locations outside and inside the root zone, respectively. The wet (T01 to T06 in Fig. 9) and dry (T07 to T10 in Fig. 9) states were analyzed separately. For the both wet and dry states, the relationship between the two predictions had a strong correlation $(r=0.9)$ for locations outside the root zone. Predictions for UP4 were quite good, especially for the wet state (Fig. 9). During the dry state, the relationship between the two predictions remained acceptable, with a smaller VWC from the retention curve (Fig. 9). A shift between the locations inside and outside the root zone indicates two different patterns. VWC values predicted from the WS model show highest soil moisture for locations inside the root zone (Fig. 9).

\section{Discussion}

Predicting VWC from ERT has become a classical approach widely used by geophysicists. The method developed has several steps summarized in Fig. 10, from data acquisition to processing. ERT, matric potential and groundwater level measurements were performed over the studied period. Particle-size distribution (PSD), bulk and root density were also characterized along the toposequence. Changes in ER over time were predicted without removing the effect of soil temperature variations over the study period, since these data were missing. PDFs of ER and matric potential were helpful for analyzing the statistical range of data and selecting the relevant monitoring time. The most contrasting times, corresponding to the wettest (T06) and driest (T10) states, were analyzed. ER and matric-potential data from the unsaturated zone were extracted to analyze the relationship between ER and matric potential (Fig. 10). ER measurements were also 


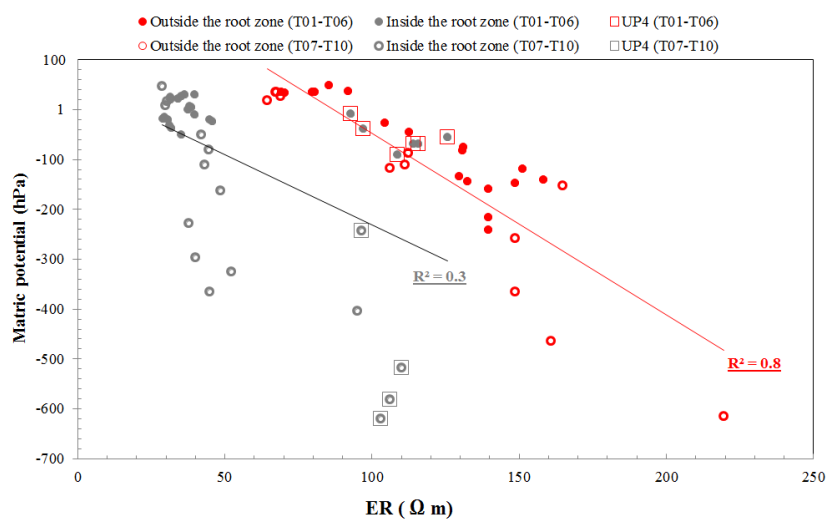

Figure 7. Relationship between matric potential and ER measured in the topsoil during the study period (T01-T10). Red and gray circles indicate the data collected regularly outside and inside the root zone, respectively. Filled circles indicate the wet period (T01-T06) and open circles the dry period (T07-T10).
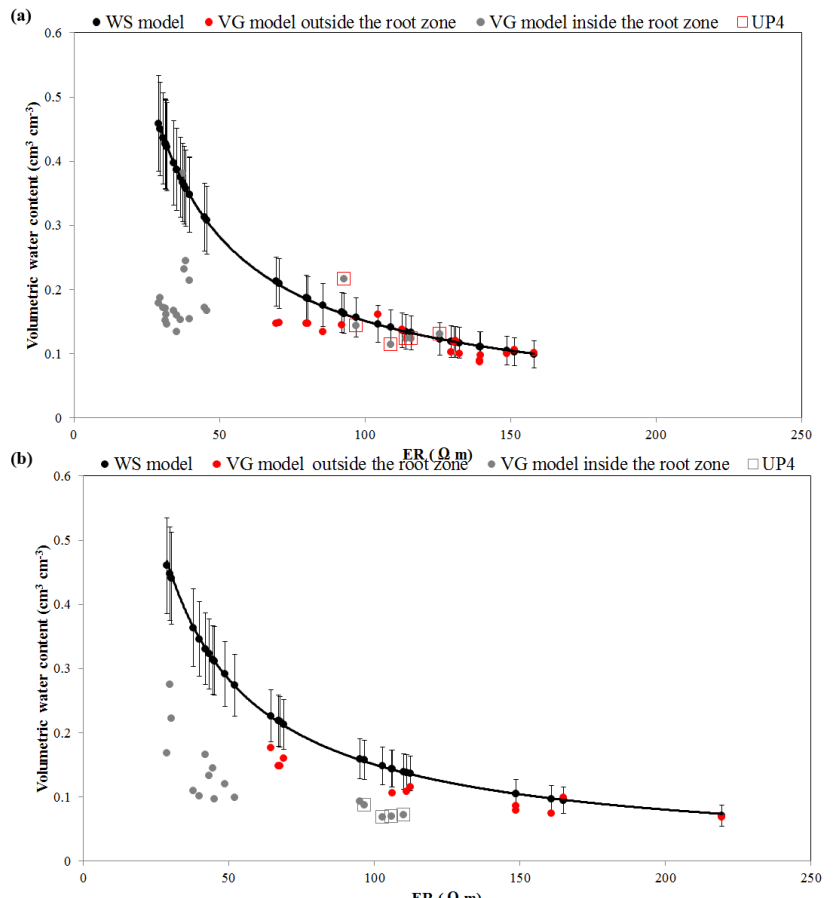

Figure 8. Relationship between VWC and ER in the topsoil for (a) the wet period (T01 to T06) and (b) the dry period (T07 to T10). Black circles with standard deviation indicate VWC from the Waxman and Smits model. Red and gray circles indicate VWC predicted from the retention curve outside and inside the root zone, respectively.

converted to VWC by a simplified petrophysical model of Waxman and Smits. VWC was also predicted using retention curves (Fig. 10). Outside the root zone, the same relationships between ER, on the one hand, and VWC and matric potential, on the other, were observed for the wet and

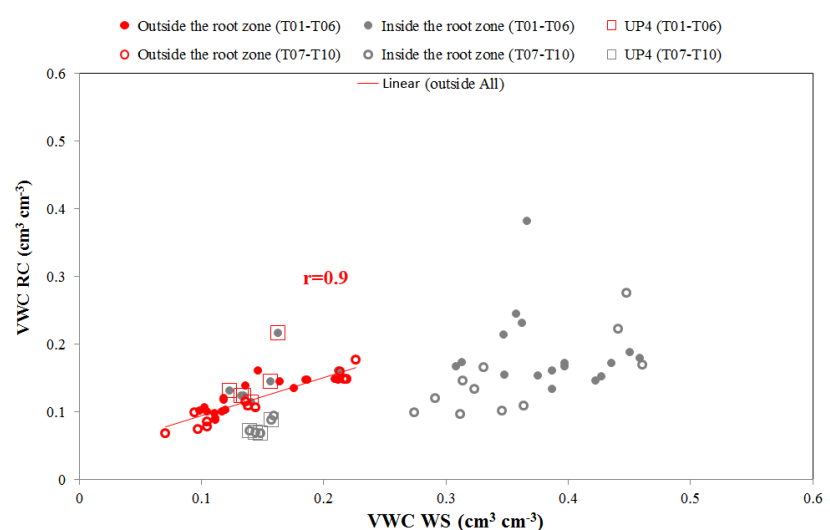

Figure 9. VWC predicted by the Waxman and Smits model compared to that predicted by the retention curve outside the root zone (red circles) and inside the root zone (gray circles). Filled circles represent the wet period (T01 to T06) and open circles the dry period (T07-T10).

dry periods. Inside the root zone, a nonstationarity in those relationships was observed (Fig. 10).

\subsection{Soil properties and horizon organization}

Vertically, ER maps revealed three main structures along the toposequence: (i) a resistive topsoil layer (Figs. 4 and S5) underlying the well-drained organo-mineral A horizon in the upslope zone, (ii) stagnic (A) and endostagnic (E, B) horizons that are more conductive (Figs. 4 and S5), (iii) deep C mineral horizon with intermediate ER (Figs. 4 and S5) and irregular structures that were probably related to the degree of weathering of the Brioverian schist.

The three main structures are intersected by a vertical conductive structure below the hedgerow (Figs. 4 and S5). We hypothesized that this structure may result from a higher degree of bedrock weathering caused by the main taproot (Baffet, 1984). The increase with clay content due to bedrock weathering caused ER to decrease in the vertical conductive structure. Near the taproot, preferential water flow also contributes to bedrock weathering.

As expected, our results show that lateral and vertical changes in ER are consistent with clay content measurements at multiple depths (Ward, 1990). In the downslope zone, clay content is $4-6 \%$ higher than in the upslope zone (Ghazavi et al., 2008). In addition, clay content increased and ER decreased with depth for all upslope locations (UP16, UP8 and UP4). ER also decreased when soil bulk density increased from the topsoil to the depth of the unsaturated zone (Fig. S2a and b). Besson et al. (2004) obtained similar results, indicating that soil ER was sensitive to bulk density. An increase in bulk density from 1.39 to 1.59 in a loamy soil corresponded to an $11 \Omega \mathrm{m}$ decrease in ER (Besson et al., 2004). 

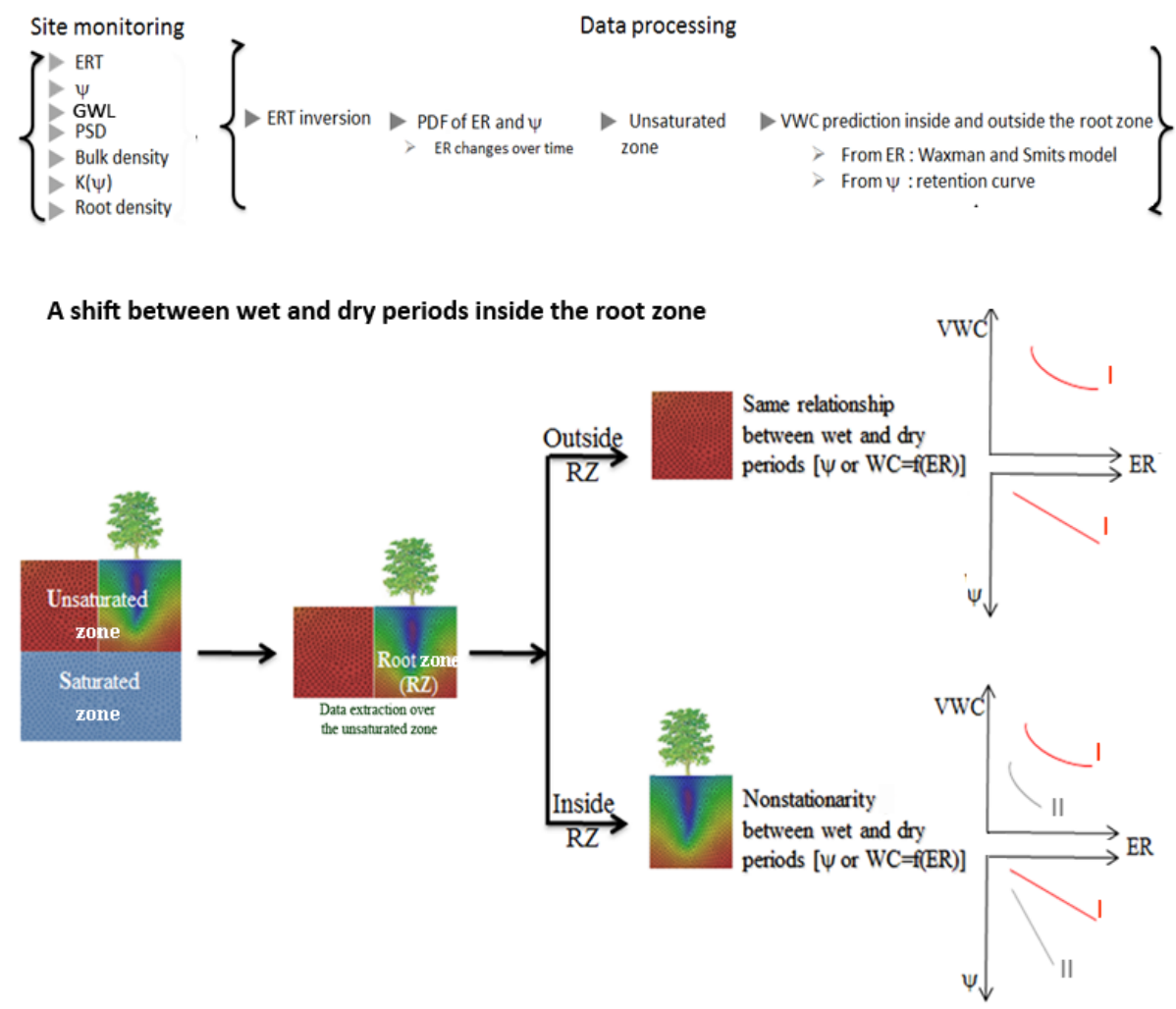

Figure 10. Conceptual diagram summarizing the monitoring setup and the main results, Outside the root zone, the same relationships between ER and VWC (or matric potential) were observed for the wet and dry periods (curve I). Two behaviors (curves I and II) were observed on the locations inside and outside the root zone.

\subsection{Spatial distribution of hedgerow roots in the unsaturated zone}

Most roots were located in the upslope zone from 0.1 to $1.0 \mathrm{~m}$ depth (61\% from 0.1 to $0.5 \mathrm{~m}$ depth and $36 \%$ from 0.5 to $1.0 \mathrm{~m}$ depth) and extended up to $6 \mathrm{~m}$ upslope from the hedgerow (Fig. S2e and f). Downslope, $92 \%$ of roots were located from 0.1 to $0.5 \mathrm{~m}$ depth and only $8 \%$ were located from 0.5 to $1.0 \mathrm{~m}$ depth (Fig. S2e and f). In addition, oak roots did not extend further than $9 \mathrm{~m}$ downslope. The temporal change in ER was largest in the topsoil layer and inside the root zone (Fig. 5a). Also, matric-potential gradients between two depths were highest near the hedgerow (Fig. 5b). They were induced by root water uptake and agree with the literature on the spatial distribution of oak root systems (Drénou, 2006; Lucot, 1994). In our study, the spatial distribution of the root system was influenced by soil characteristics and anthropogenic features such as the ditch and the embankment on which the hedgerow was planted. Investigation of root depth along the toposequence was limited by a compact soil layer with a high bulk density of 1.6 (Fig. S2a and b) starting at a depth of $0.6 \mathrm{~m}$.

In agreement with previous observations (Amato et al., 2008; Al Hagrey, 2007; Rossi et al., 2011), our results show several highly resistive areas close to the tree trunk (Figs. 4 and S5). Increases in ER between the wet and dry states (Fig. 5) likely identify the spatial limits of the hedgerow root system highlighting a three-pronged pattern inside the root zone. Rossi et al. (2011) demonstrated that ER variability in an orchard was related only to root biomass density. In our experiment, quantitative analysis of the relationship between ER and root density was not relevant, since their locations in the toposequence were not exactly the same.

\subsection{Consistency between ER and matric potential}

Changes in ER are related to parameters such as volumetric water content, solute concentration and temperature (Ward, 1990). According to our experimental design, changes in ER were compared to those in soil matric potential, which were converted into volumetric water content by using the measured retention curve (Sect. 4.4).

Two different behaviors in the relationship between ER and matric potential were observed between locations outside the root zone (UP16, UP8 and DW12) and those inside the root zone (UP4, UP1, DW2 and DW6), with $R^{2}$ values of 0.8 and 0.3 , respectively (Fig. 7). However, for UP4, this relationship adequately fit the curve obtained outside the root zone during the wet state (T01-T06). Despite high root density, UP4 showed the same behavior as the locations outside 
the root zone. The wet and leafless period, which occurred from autumn to the beginning of spring, without transpiration (Thomas et al., 2012), was characterized by no influence from the root system. The ER-matric-potential relationship of UP4 followed the locations outside the root zone during the wet state. For the dry state, ER values do not change despite a change in matric potential. For this location, a decrease in matric potential was related to a small change in ER values. Inside the root zone, the relationship between matric potential and ER had high variability from wet to dry states, probably caused by soil heterogeneity (Fig. 7). A decrease in matric potential (from -100 to $-650 \mathrm{hPa}$ ) inside the root zone was related to a small change in ER. At our study site, the hedgerow with a bank and a ditch increased soil variability (Fig. 1). Moreover, as described by Hesse (1990), variation in topography modifies bulk ER measurements for a given electrode array. For a homogeneous soil system, bulk ER decreases over a bank and increases over a ditch (Hesse, 1990). Topographical singularities create anomalies in ER values.

The ability of ER to predict soil matric potential was quite good along the toposequence outside the root zone (Fig. 7). We hypothesized that the many singularities around the hedgerow, combined with the high root density, increased the signal-to-noise ratio. Considering the shift in mean ER (PDF in Fig. 6a) between the wettest (T06) and driest (T10) states, the decrease in matric potential did not change the shape of ER distributions but only their mean values, which was highest when the soil was drier. Matric-potential profiles (Fig. 5b) showed a drier zone inside the root zone.

\subsection{VWC prediction using ER inside and outside the root zone}

By analyzing 27 simulations from the WS model, our results highlight the sensitivity of VWC prediction to WS parameters (standard deviation: $0.030-0.014 \%$ ). Outside the root zone, VWC values predicted by the WS model were consistent with those from the retention curve (Fig. 8), suggesting the ability of ER to predict soil moisture in a homogeneous soil system. Differences in VWC prediction inside the root zone were observed for both wet and dry states (Fig. 8). Moreover, ER values were smaller than $50 \Omega \mathrm{m}$, indicating limitations of the WS model. As suggested by Laloy et al. (2011), among five petrophysical models tested on a loamy soil to predict VWC and soil bulk density, the Waxman and Smits model appeared more consistent for electrical resistivity values $>100 \Omega \mathrm{m}$, which are often observed in dry soils. For lower ER values $(<100 \Omega \mathrm{m})$, the volumeaveraging method (Pride, 1994; Linde et al., 2006) outperformed other tested models. In our study, the bad results obtained from the WS model are probably related to the inconsistency in parameters as soil water electrical conductivity changes with soil moisture inside the root zone. Outside the root zone, a good agreement between WS and retention curve predictions during the wet state highlights the ability of ER to predict soil moisture (Fig. 9). A linear relationship was observed between VWCs predicted by the WS model and the retention curve. Inside the root zone, VWC predicted with the WS model overestimated soil moisture for both wet and dry states. Overestimation of soil moisture inside the root zone was probably related to soil heterogeneity. Also, shallow groundwater up to $2 \mathrm{~m}$ deep maintained a relatively wet soil along the toposequence. No change in water content occurred, since all the pores of the saturated zone were occupied by water. We conclude that changes in ER were probably related to changes in electrical conductivity of soil water. We also observed a high chloride concentration below the hedgerow in the same toposequence (Grimaldi et al., 2009). It is well known that ER decreases when ionic concentration increases (Ward, 1990). Since chloride is a conservative solute, its concentration increased with water and nutrient uptake. At this location, the highly conductive structures (Figs. 4 and S5) were observed below the hedgerow, in agreement with observations of chloride concentration (Grimaldi et al., 2009). These structures, probably due to a high chloride concentration, moved little over time on the ER maps (T01 to T10, Fig. S5). The conductive structure observed at UP1 from T01 to T04 disappeared at T05 due to high rainfall (Figs. 2a and S5). Rainfall events observed between T04 and T05 should have diluted solutes. Another conductive structure below the hedgerow appeared at $\mathrm{T} 07$ and at T09, when root water uptake was highest. Change in conductive zones and their small degree of movement was probably related to water fluxes and chloride concentration.

To analyze the relationship between soil ER and individual parameters, further studies are needed. High-resolution analysis should be performed by monitoring chloride concentration, ER and soil matric potential at the same spatial (grid size) and temporal resolutions. In this way, the perspective of using ER maps as a proxy for chloride accumulation in the vadose zone could be addressed.

The originality of our approach consists in analyzing both spatial and temporal effects of soil moisture. Spatial effects of the root zone induced a nonstationarity of the relationship between VWC (or $\psi$ ) and ER (Fig. 10) for dry and wet periods. The temporal effect was mainly controlled by the seasonality (wet and the dry periods), which is well known as a first-order forcing.

\section{Conclusion}

ERT monitoring offers a noninvasive tool with a high resolution, providing information about soil horizon geometry as well as physical and chemical properties. The geophysical signal reveals combined contributions from the main parameters (i.e., structure, water content, fluid composition), but their individual effects are more difficult to assess. 
The hydrological year studied was particularly wet. The PDFs of ER and matric-potential measurements for wettest and driest states show the largest difference in mean values in the topsoil layer. The relationship between ER and matric potential highlights different trends inside and outside the root zones. Also, the heterogeneous zone, below the hedgerow, identified using ER changes and matric-potential profiles, were consistent with vertical and horizontal root density. Two different behaviors for locations inside and outside the root zone were identified. A strong correlation between VWC values predicted by the Waxman and Smits model and those obtained by the retention curve was observed outside the root zone $(r=0.9)$. In contrast, ER and soil moisture have a weak correlation at the hedgerow proximity. A shift in the VWC from Waxman and Smits and the retention curve was observed inside the root zone revealing the nonstationarity in this relationship between wet and dry periods. The non-unequivocal behavior of this relationship shows the limitation of using ER to predict soil moisture in a heterogeneous soil system. Similar monitoring with ERT should be extended to a variety of toposequences with contrasting interaction between topography and soil structures on the rhizosphere. More investigations of heterogeneous soil systems would help to determine whether ERT measurements are appropriate to predict soil moisture of heterogeneous soil systems. In many hedgerow landscapes where the density of linear vegetation structure is high, heterogeneities on the rhizosphere are mainly due to human activities which modify landscapes by creating topographical singularities such as ditches and banks. In the particular topographical context of our case study, soil heterogeneities inside the root zone are mainly related to the high root density below the ditch-bankhedgerow system. Such systems are commonly encountered in Brittany and throughout northwestern Europe.

\section{The Supplement related to this article is available online at doi:10.5194/soil-2-241-2016-supplement.}

Acknowledgements. Part of this work was supported by the ECOGER project ACI Ecco. The authors thank INRA and AGROCAMPUS OUEST for supporting this research. The Mogis and Courtillon families kindly permitted the installation of experimental equipment on their fields.

Edited by: N. J. Kuhn

\section{References}

Adam, I., Michot, D., Guero, Y., Soubega, B., Moussa, I., Dutin, G., and Walter, C.: Detecting soil salinity changes in irrigated Vertisols by electrical resistivity prospection during a desalinisation experiment, Agr. Water Manage., 109, 1-10, doi:10.1016/j.agwat.2012.01.017, 2012.

Al Hagrey, S. A.: Geophysical imaging of root-zone, trunk, and moisture heterogeneity, J. Exp. Bot., 58, 839-854, doi:10.1093/jxb/erl237, 2007.

Al Hagrey, S. A. and Michaelsen, J.: Resistivity and percolation study of preferential flow in vadose zone at Bokhost, Germany, Geophysics, 64, 746-753, 1999.

Al Hagrey, S. A. and Petersen, T.: Numerical and experimental mapping of small root zones using optimized surface and borehole resistivity tomography, Geophysics, 76, 25-35, 2011.

Amato, M., Basso, B., Celano, G., Bitella, G., Morelli, G., and Rossi, R.: In situ detection of tree root distribution and biomass by multi-electrode resistivity imaging, Tree Physiol., 28, 14411448, 2008.

Amato, M., Bitella, G., Rossi, R., Gómez, J. A., Lovelli, S., and Gomes, J. J. F.: Multi-electrode 3D resistivity imaging of alfalfa root zone, Eur. J. Agron., 31, 213-222, doi:10.1016/j.eja.2009.08.005, 2009.

Archie, G. E.: The electrical resistivity $\log$ as an aid in reservoir characteristics, T. AIME, 146, 54-62, 1942.

Baffet, M.: Influence de la haie sur l'évolution des caractères physico-chimiques et hydrodynamiques des sols, Thèse de doctorat de l'Université de Limoges, Limoges, 173 pp., 1984.

Beff, L., Günther, T., Vandoorne, B., Couvreur, V., and Javaux, M.: Three-dimensional monitoring of soil water content in a maize field using Electrical Resistivity Tomography, Hydrol. Earth Syst. Sci., 17, 595-609, doi:10.5194/hess-17-595-2013, 2013.

Besson, A., Cousin, I., Samouëlian, A., Boizard, H., and Richard, G.: Structural heterogeneity of the soil tilled layer as characterized by 2D electrical resistivity surveying, Soil Till. Res., 79, 239-249, 2004.

Bréda, N., Granier, A., Barataud, F., and Moyne, C.: Soil-water dynamic in an oak stand. I. Soil moisture, water potentials, and water uptake by roots, Plant Soil, 172, 17-27, 1995.

Brillante, L., Bois, B., Mathieu, O., Bichet, V., Michot, D., and Lévêque, J.: Monitoring soil volume wetness in heterogeneous soils by electrical resistivity. A field-based pedotransfer function, J. Hydrol., 516, 55-66, doi:10.1016/j.jhydrol.2014.01.052, 2014.

Brillante, L., Mathieu, O., Bois, B., van Leeuwen, C., and Lévêque, J.: The use of soil electrical resistivity to monitor plant and soil water relationships in vineyards, SOIL, 1, 273-286, doi:10.5194/soil-1-273-2015, 2015.

Caubel, V.: Influence de la haie de ceinture de fond de vallée sur les transferts d'eau et de nitrate, Thèse de Doctorat de l'Ecole Nationale des Sciences Agronomiques de Rennes, Rennes, 155 pp., 2001.

Decagon Devices.: Mini disk infiltrometer, Model S, user's manual version 3, Decagon devices, Pullman, WA, 21 pp., 2006.

Descloitres, M., Ribolzi, O., Le Troquer, Y., and Thiébaux, J. P.: Study of water tension differences in heterogeneous sandy soils using surface ERT, J. Appl. Geophys., 64, 83-98, 2008. 
Drénou, C.: Les racines, face cachée des arbres, Institut pour le développement forestier, Paris, 335 pp., 2006.

FAO: World Reference Base for Soil Resources, IUSS Working Group, 2nd Edn., FAO, World Soil Resources Report No. 103, FAO, Rome, 128 pp., 2006.

Ferren, J. C.: Monographie du climat, Station de Rennes-Le Rheu, Analyse sur 30 années des moyennes mensuelles 1971-2000, INRA, Rennes, 9 pp., 2004.

Follain, S., Walter, C., Bonté, P., Marguerie, D., and Lefevre, I.: Ahorizon dynamics in a historical hedged landscape, Geoderma, 150, 334-343, 2009.

Garré, S., Javaux, M., Vanderborght, J., Pagès, L., and Vereecken, H.: Three-dimensional electrical resistivity tomography to monitor root zone water dynamics, Vadose Zone J., 10, 412-424, 2011.

Garré, S., Günther, T., Diels, J., and Vanderborght, J.: Evaluating experimental design of ERT for soil moisture monitoring in contour hedgerow inter-cropping systems, Vadose Zone J., 11, doi:10.2136/vzj2011.0186, 2012.

Garré, S., Coteur, I., Wongleecharoen, C., Kongkaew, T., Diels, J., and Vanderborght, J.: Noninvasive monitoring of soil water dynamics in mixed cropping systems. A case study in Ratchaburi Province, Thailand, Vadose Zone J., 12, doi:10.2136/vzj2012.0129, 2013.

Ghazavi, G., Thomas, Z., Hamon, Y., Marie, J. C., Corson, M., and Merot, P.: Hedgerow impacts on soil-water transfert due to rainfall interception and root-water uptake, Hydrol. Process., 22, 4723-4735, 2008.

Ghazavi, G., Thomas, Z., Hamon, Y., and Merot, P.: Spatial and temporal variation of soil-water movement under a hillslope hedgerow during contrasting meteorological conditions, Hydrol. Process., 25, 1431-1442, 2011.

Grimaldi, C., Thomas, Z., Fossey, M., Fauvel, Y., and Merot, P.: High chloride concentrations in the soil and groundwater under an oak hedge: an indicator of evapotranspiration and water movement, Hydrol. Process., 23, 1865-1873, 2009.

Hadzick, Z. Z., Guber, A. K., Pachepsky, Y. A., and Hill, R. L.: Pedotransfer functions in soil electrical resistivity estimation, Geoderma, 164, 195-202, doi:10.1016/j.geoderma.2011.06.004, 2011.

Hesse, A.: Resistivity prospecting, in: Archaeological prospecting and remote sensing, edited by: Scollar, I., Tabbagh, A., Hesse, A., and Herzog, I., Cambridge University Press, Cambridge, 307374, 1990.

Laloy, E., Javaux, M., Vanclooster, M., Roisin, C., and Bielders, C. L.: Electrical resistivity in a loamy soil: identification of the appropriate pedo-electrical model, Vadose Zone J., 10, 1023-1033, doi:10.2136/vzj2010.0095, 2011.

Linde, N., Binley, A., Tryggvason, A., Pedersen, L. B., and Revil, A.: Improved hydrogeophysical characterization using joint inversion of crosshole electrical resistance and groundpenetrating radar traveltime data, Water Resour. Res., 42, W12404, doi:10.1029/2006WR005131, 2006.

Loke, M. H. and Barker, R. D.: Rapid least-squares inversion of apparent resistivity pseudo-sections by a quasi-Newton method, Geophys. Prospect., 44, 131-152, 1996.

Lucot, E.: Influence des caractéristiques de la piérrosité des sols sur la prospection racinaire et l'alimentation hydrique des arbres. Application à l'estimation de la valeur des sols forestiers,
Thèse de doctorat de l'Université de Franche-Comté, Besançon, 101 pp., 1994.

Michot, D.: Intérêt de la géophysique de subsurface et de la télédétection multispectrale pour la cartographie des sols et le suivi de leur fonctionnement hydrique à l'échelle intraparcellaire, Thèse de l'Université Paris VI, Paris, 394 pp., 2003.

Michot, D., Dorigny, A., and Benderitter, Y.: Determination of water flow direction and corn roots-induced drying in an irrigated Beauce CALCISOL, using electrical resistivity measurements, Comptes Rendus De L'Academie Des Sciences Serie II Fascicule a-Sciences De La Terre Et Des Planetes, 332, 29-36, 2001.

Michot, D., Benderitter, Y., Dorigny, A., Nicoullaud, B., King, D., and Tabbagh, A.: Spatial and temporal monitoring of soil water content with an irrigated corn crop cover using surface electrical resistivity tomography, Water Resour. Res., 39, 1138-1158, 2003.

Müller, K., Vanderborght, J., Englert, A., Kemna, A., Huisman, J. A., Rings, J., and Vereecken, H.: Imaging and characterization of solute transport during two tracer tests in a shallow aquifer using electrical resistivity tomography and multilevel groundwater samplers, Water Resour. Res., 46, W03502, doi:10.1029/2008WR007595, 2010.

Nijland, W., van der Meijde, M., Addink, E. A., and de Jong, S. M.: Detection of soil moisture and vegetation water abstraction in a Mediterranean natural area using electrical resistivity tomography, Catena, 81, 209-216, 2010.

Pride, S.: Governing equations for the coupled electromagnetics and acoustics of porous media, Phys. Rev. B, 50, 15678-15696, doi:10.1103/PhysRevB.50.15678, 1994.

Rossi, R., Amato, M., Bitella, G., Bochicchio R., Ferreira Gomes, J. J., Lovelli, S., Martorella, E., and Favale, P.: Electrical resistivity tomography as a nondestructive method for mapping root biomass in an orchard, Eur. J. Soil Sci., 62, 206-215, doi:10.1111/j.1365-2389.2010.01329.x, 2011.

Samouëlian, A., Cousin, I., Tabbagh, A., Bruand, A., and Richard, G.: Electrical resistivity survey in soil science: a review, Soil Till. Res., 83, 173-193, 2005.

Srayeddin, I. and Doussan, C.: Estimation of the spatial variability of root water uptake of maize and sorghum at the field scale by electrical resistivity tomography, Plant Soil, 319, 185-207, 2009.

Thomas, Z., Molénat, J., Caubel, V., Grimaldi, C., and Mérot P.: Simulating soil-water movement under a hedgerow surrounding a bottomland reveals the importance of transpiration in water balance, Hydrol. Process., 22, 577-585, 2008.

Thomas, Z., Ghazavi, R., Merot, P., and Granier, A.: Modelling and observation of hedgerow transpiration effect on water balance components at the hillslope scale in Brittany, Hydrol. Process., 26, 4001-4014, 2012.

Van Genuchten, M. T.: A Closed-form equation for predicting the hydraulic conductivity of unsaturated soils, Soil Sci. Soc. Am. J., 44, 892-898, 1980.

Walter, C., Mérot, P., Layer, B., and Dutin, G.: The effect of hedgerows on soil organic carbone storage in hillslopes, Soil Use Manage., 19, 201-207, 2003.

Ward, S. H. (Ed.): Resistivity and induced polarization methods, in: Investigations in Geophysics No. 5, Geotechnical and Environmental Geophysics, Society of Exploration Geophysicists, Tulsa, Oklahoma, 147-189, 1990. 
Waxman, M. H. and Smits, L. J. M.: Electrical conductivities in oil-bearing shaly sands, Soc. Pet. Eng. J., 8, 107-122, doi:10.2118/1863-A, 1968.

Werban, U., al Hagrey, S. A., and Rabbel, W.: Monitoring of rootzone water content in the laboratory by $2 \mathrm{D}$ geoelectrical tomography, J. Plant Nutr. Soil Sci., 171, 927-935, 2008.

Wooding, R. A.: Steady infiltration from a shallow circular pond, Water Resour. Res., 4, 1259-1273, 1968.

Yamakawa, Y., Kosugi, K., Katsura, N., Masaoka, N., and Mizuyama, T.: Spatial and temporal monitoring of water content in weathered granitic bedrock using electrical resistivity imaging, Vadose Zone J., 11, doi:10.2136/vzj2011.0029, 2012.
Zenone, T., Morelli, G., Teobaldelli, M., Fischanger, F., Matteucci, M., Sordini, M., Armani, A., Ferre, C., Chiti, T., and Seufert, G.: Preliminary use of ground penetrating radar and electrical resistivity tomography to study tree roots in pine forests and poplar plantations, Funct. Plant Biol., 35, 1047-1058, 2008.

Zhou, Q. Y., Shimada, J., and Sato, A.: Three-dimensional spatial and temporal monitoring of soil water content using electrical resistivity tomography, Water Resour. Res., 37, 273-285, 2001. 